\title{
Fibrous Monolithic Ceramics: III, Mechanical Properties and Oxidation Behavior of the Silicon Carbide/Boron Nitride System
}

\author{
Suresh Baskaran ${ }^{\star \star}$ and John W. Halloran* \\ Department of Materials Science and Engineering, University of Michigan, \\ Ann Arbor, Michigan 48109-2136
}

\begin{abstract}
Fibrous monolithic ceramics were fabricated in the $\mathrm{SiC} / \mathrm{BN}$ system. The microstructure consists of high-aspect-ratio polycrystalline cells of $\mathrm{SiC}$ separated by cell boundaries of BN. The fibrous monolith with aligned cells fails noncatastrophically in flexure, with delamination cracking along the BN cell boundaries. Indentations cause controlled damage on the surface, but no strength-degrading flaws. The flexural strength is in the range $300-375 \mathrm{MPa}$, and the estimated shear strength is $\approx 14 \mathrm{MPa}$. The $\mathrm{SiC} / \mathrm{BN}$ fibrous monoliths also show excellent resistance to high-temperature oxidation in air. Noncatastrophic fracture behavior is observed at room temperature after heat treatments between $1200^{\circ}$ and $1500^{\circ} \mathrm{C}$. The $\mathrm{SiC}$ cells on the surface are oxidized to form a protective silicate scale, which prevents deterioration of the $\mathrm{BN}$ cell boundaries.
\end{abstract}

\section{Introduction}

T HE incorporation of high-strength ceramic fibers in ceramic matrices has led to a new generation of advanced composites with high toughness and graceful failure characteristics. ${ }^{1,2}$ Fiber-reinforced ceramic matrix composites are candidate materials for many lightweight, high-temperature structural applications such as gas turbine engine components. However, these materials have found only limited use because of their high cost. Composites use expensive fibers, and must be fabricated using costly processing methods such as coatings by chemical vapor deposition and, in some cases, matrix formation by chemical vapor infiltration. A monolithic ceramic material fabricated with inexpensive powders and showing noncatastrophic fracture behavior would prove to be more useful. Clegg et al ${ }^{3}$ demonstrated this concept with tough SiC/graphite tapecast laminates in which the graphite interlayers delaminated during flexural failure. Similarly, SiC-based ceramics fabricated from powders by the "fibrous monolith" approach ${ }^{4}$ have shown useful mechanical properties. ${ }^{5,6}$ These new materials have commercial potential because of their damage-tolerant mechanical behavior combined with low cost.

The "fibrous monolith" microstructure consists of highaspect-ratio polycrystalline cells of a primary phase separated by thin cell boundaries of a second phase. ${ }^{5}$ There are no reinforcing fibers. The cells are polycrystalline regions (e.g., SiC) that are remnants of "green" powder-loaded polymer fibers. A coating applied on the green fiber forms the cell boundary, which can be any thermodynamically compatible second phase designed to enhance the fracture resistance of the material. When the cell boundary is graphite, there is preferred crack

K. Jakus-contributing editor

Manuscript No. 194350. Received July 23, 1993; approved January 31, 1994

Supported by the Advanced Research Projects Agency and the Office of Naval Research under Contract No, N0014-91-J-1999.

"Member, American Ceramic Society.

'Now with Battelle Pacific Northwest Laboratory, Richland, WA. propagation along the cell boundaries. The fibrous monolith fails noncatastrophically in flexure and is flaw-tolerant and notch-insensitive. ${ }^{6}$

$\mathrm{SiC} /$ graphite fibrous monoliths have limited applications because of oxidation of the graphite cell boundaries at high temperatures in air. Thermogravimetric analysis of $\mathrm{SiC} / g r a p h-$ ite fibrous monoliths has shown that weight loss due to oxidation of cell boundaries begins at $\approx 250^{\circ} \mathrm{C}$ and is complete after $1 \mathrm{~h}$ at $700^{\circ} \mathrm{C} .{ }^{7} \mathrm{An}$ alternative weak cell boundary material with better oxidation resistance is hexagonal $(\alpha)$ boron nitride, which is similar in structure to graphite. High-performance fiber-reinforced composites have been fabricated with CVD coatings of $\mathrm{BN}$ on fibers. ${ }^{8-10}$ The weak $\mathrm{BN}$ interfacial layers between fibers and matrix result in debonding and fiber pullout, giving rise to useful fracture behavior. In this paper, processing and mechanical properties of $\mathrm{SiC} / \mathrm{BN}$ fibrous monoliths are described. Fracture behavior is compared with $\mathrm{SiC}$ monolith and $\mathrm{SiC} /$ graphite fibrous monolith. ${ }^{6.11}$ The effect of oxidation is evaluated by microstructural analysis and room-temperature flexural tests after high-temperature treatments in air.

\section{Experimental Procedure}

Suspensions of $\mathrm{SiC}$ powder (B-10, $\beta$-SiC powder, H. C. Starck, New York) in an ethyl methacrylate (EMA)/methyl ethyl ketone (MEK) solution (B7/MEK Acryloid, 30 wt\% solution, Rohm and Haas, Philadelphia, PA) were ball-milled, and then concentrated by evaporation of the MEK. The concentrated "dopes" were extruded to form soft "green fibers" by dryspinning into a hot-air column maintained at $100^{\circ} \mathrm{C}$. Yttria (Johnson Matthey, Ward Hill, MA) and alumina (RC-HP DBM, Malakoff Industries, Malakoff, TX) were used as sintering aids. The weight ratio of $\mathrm{SiC}: \mathrm{Y}_{2} \mathrm{O}_{3}: \mathrm{Al}_{2} \mathrm{O}_{3}$ was $90: 4: 6$. The volume ratio of ceramic powder to ethyl methacrylate polymer in the dry fiber was 55:45. Green fibers typically had a "dog-bone" cross section, ${ }^{5}$ with an area-equivalent circular diameter of $\approx 150-200 \mu \mathrm{m}$.

The green fibers were run through a coating slurry of $\mathrm{BN}\left(+\mathrm{Al}_{2} \mathrm{O}_{3}\right)^{\ddagger}$ immediately after extrusion. Boron nitride was present as $1-10-\mu \mathrm{m}$-wide platelets in suspension. The coated fibers were loaded in a $52 \mathrm{~mm} \times 26 \mathrm{~mm}$ graphite die using one of two fiber architectures: either aligned fibers using $\approx 51-\mathrm{mm}$ lengths or finely chopped, randomly oriented fiber segments. To simply evaluate the fracture behavior, both die filling techniques were tested. To study the effect of oxidation treatments, only aligned fiber billets were used. The chopped fiber die-filling method was evaluated because it was relatively easy.

The green fibers were pressed at $\approx 80^{\circ} \mathrm{C}$, using 5 -MPa pressure. This softens the polymer and consolidates the fibers into a dense monolithic billet with $45 \mathrm{vol} \%$ polymer. After removal of the polymer binder between $200^{\circ} \mathrm{C}$ and $600^{\circ} \mathrm{C}$ in an actively pumped vacuum, the billet was hot-pressed at $1900^{\circ} \mathrm{C}$ in argon

\footnotetext{
'ZYP paint, (25 weight parts BN, 5 parts hydrated alumina, 70 parts water), ZYP Inc., Oak Ridge, TN. Actual ceramic solids was $87.5 \mathrm{wt} \% \mathrm{BN}, 12.5 \mathrm{w} \% \mathrm{Al}_{2} \mathrm{O}_{3}$.
} 
for $1 \mathrm{~h}$, using 25-MPa ram pressure. Hot-pressed billets were $4.0-4.5 \mathrm{~mm}$ in thickness.

Most hot-pressed billets were machined into bar specimens 3 $\mathrm{mm}$ thick, $4 \mathrm{~mm}$ wide, and $48 \mathrm{~mm}$ long. Three bar specimens from an aligned fiber billet were machined down to $1-\mathrm{mm}$ thickness. The 3-mm-thick samples provided a span-to-depth ratio of 3.33, which caused samples to fail by midplane shear cracking. ${ }^{6.12}$ The $1-\mathrm{mm}$-thick samples were used to evaluate the true flexural strength of the material at high $(\approx 9)$ span-to-depth ratio. All bars were machined and chamfered with a 1000-grit resin-bonded diamond wheel, with the grinding direction parallel to the length of the specimen. The tension side was normal to the pressing direction. In some cases, the side surfaces of samples were polished prior to testing. Flexural strength was measured using a fully articulated four-point bend fixture with a 20-mm inner span and a 40 -mm outer span at a crosshead speed of $0.05 \mathrm{~mm} / \mathrm{min}$. Stress values were calculated from elastic beam equations.

The density of the bars was measured by the Archimedes method. Young's modulus was measured on bar specimens by the flexural resonance method ${ }^{13,14}$ (Grindo-Sonic, J. W. Lemmens, St. Louis, MO). In this technique, the bar is set in resonance, and the frequency is measured with a contact probe. Damage and cracking from Vickers indentations were studied using a Zwick (E. Windsor, CT) indenter. An indentation load of $5 \mathrm{~kg}(\approx 50 \mathrm{~N})$ was used with 30 -s residence time.

Machined bar specimens of 3-mm thickness were heattreated in air at high temperatures. Bars were held for $10 \mathrm{~h}$ between $1200^{\circ}$ and $1500^{\circ} \mathrm{C}$. Some bars were also held at $1400^{\circ} \mathrm{C}$ for 10,50 , and $250 \mathrm{~h}$. Heating and cooling rates were $15^{\circ} \mathrm{C} / \mathrm{min}$ between $\approx 500^{\circ} \mathrm{C}$ and the heat-treatment temperature. Heat-treated bars were tested in flexure. The 3-mm-thick specimens were used to study the effect of oxidation on the material's shear characteristics which are responsible for the noncatastrophic fracture behavior.

After testing, all heat-treated bars were inspected, using optical and scanning electron microscopy. Bars invariably shear cracked on only one-half of the specimen. Cross sections $\approx 5 \mathrm{~mm}$ from the undamaged end were polished and then studied by optical microscopy. Elemental analysis was done on polished sections with an electron microprobe, using X-ray wavelength dispersive spectrometry and appropriate standards.

\section{Results and Discussion}

\section{(1) Microstructure, Elastic Modulus, and Indentation Behavior}

The microstructure of $\mathrm{SiC} / \mathrm{BN}$ fibrous monoliths with aligned fibers is shown in Fig. 1. Flattened SiC cells 50-100 $\mu \mathrm{m}$ thick and $150-200 \mu \mathrm{m}$ wide are separated by cell boundaries a few micrometers to $\approx 25 \mu \mathrm{m}$ in thickness. The cell sections visible in the micrographs of Figs. 1(A) and (C) vary in length from about $200 \mu \mathrm{m}$ to several millimeters in the long direction of the billet. Although long green fibers are placed in the die, the forming procedure can result in finite cell lengths. Green fibers can fracture or bend and also may not lie perfectly normal to the pressing direction or perfectly parallel to the long die wall. Only short cell segments are visible in the micrographs, but individual cells could actually have continuity and extend for longer distances (approximately a few centimeters) up to a maximum of $5.2 \mathrm{~cm}$.

The microstructure of a chopped fiber monolith is shown in Fig. 2. Here the cell cross sections on surfaces parallel to the pressing direction are quite small. Cell lengths vary from 200 to $600 \mu \mathrm{m}$. Viewed in the pressing direction, the sample consists of randomly oriented cells several hundred micrometers long and about $200 \mu \mathrm{m}$ wide.

The volume fraction of the cell boundary was determined to be $\approx 23 \mathrm{vol} \%$ from point counts on optical micrographs of cell cross sections. The analyzed area encompassed about 300 cells. The 23 vol\% cell boundary in $\mathrm{SiC} / \mathrm{BN}$ is considerably more than the 8 vol\% cell boundary in $\mathrm{SiC} /$ graphite. ${ }^{6}$ This reflects the differences in coating thickness from the commercial BN slurry used in this study and the diluted Aquadag (Acheson Colloid, Port Huron, MI) graphite slurry used to fabricate SiC/graphite. ${ }^{6}$

The $\mathrm{SiC}$ cell microstructure is shown in Fig. 3. The backscattered electron image from the electron microprobe shows elongated grains of $\mathrm{SiC}$ with the yttria-alumina intergranular phase in bright contrast. The cell phase determined by X-ray diffraction was predominantly $\beta-\mathrm{SiC}$, with $10-20 \mathrm{vol} \%$ hexagonal $\mathrm{SiC}$ polytypes.

The density of the $\mathrm{SiC} / \mathrm{BN}$ fibrous monolith was $2.99 \mathrm{~g} / \mathrm{cm}^{3}$. The samples did not imbibe water. The density of the cells is inferred by comparison to the $\mathrm{SiC}$ monolith (i.e., hot-pressed $\mathrm{SiC}$ with yttria and alumina), which was $3.20 \mathrm{~g} / \mathrm{cm}^{3}$. By combining this information, the cell boundaries are estimated to be $\approx 96$ vol\% $\mathrm{BN}\left(+\mathrm{Al}_{2} \mathrm{O}_{3}\right)$ and $\approx 4$ vol\% porosity.

For aligned fibrous monoliths, Young's modulus measured on two bar specimens was 341-342 GPa. Single-phase polycrystalline $\mathrm{SiC}$ densified with small additions of $\mathrm{B}$ and $\mathrm{C}$ has modulus ranging from 410 to $440 \mathrm{GPa}{ }^{15}$ The lower modulus compared to $\mathrm{SiC}$ reflects the contributions from $\approx 8$ vol\% yttria-alumina within cells and the high volume fraction of the lower-modulus BN cell boundary phase. The modulus of hotpressed single-phase hexagonal $\mathrm{BN}$ is in the range $35-72 \mathrm{GPa},{ }^{16}$ and there is $\approx 23$ vol\% of this cell boundary. Literature values of Young's modulus values for $\mathrm{SiC} / \mathrm{BN}$ particulate composites with $20 \mathrm{vol} \% \mathrm{BN}$ are in the range $260-320 \mathrm{GPa} .{ }^{17}$ The elastic modulus of $\mathrm{SiC} /$ graphite fibrous monolith measured by the same technique was slightly higher at 355-360 GPa, presumably due to lower ( $\approx 8$ vol\%) cell boundary content. " Combined with the low density, the modulus of the aligned fiber $\mathrm{SiC} / \mathrm{BN}$ makes this material useful in applications requiring high specific modulus.

For the chopped-fiber layout, the modulus was significantly lower $(275 \mathrm{GPa})$. The lower modulus can arise from both cell geometry considerations and BN texture within the cell boundaries. With the chopped-fiber layout, many cells lie at orientations almost perpendicular to the bar axis. A higher volume fraction of the BN cell boundaries lies in series with the $\mathrm{SiC}$ in the axial direction of the bar, resulting in lower stiffness. Furthermore, the coating process and the compaction could result in some alignment of cell boundary platelets along cell axes. In the randomly oriented cell geometry, where cells can lie normal to the bar axis, a significant fraction of $\mathrm{BN}$ platelets at the cell boundaries could be oriented with their weak $c$-axis direction along the bar axis. This could also result in lower elastic modulus.

From scanning electron microscopy of polished cross sections, it was difficult to determine whether platelets had preferred orientation. But X-ray diffraction of an aligned fiber monolith showed evidence of texture in the $\mathrm{BN}$ cell boundaries. The integrated intensity ratios of $(002)_{\mathrm{BN}}$ to $(001)_{\mathrm{b}-\mathrm{SiC}}$ were $1: 1.2,1: 4.2$ and $1: 15$ from the sample cross sections shown in Figs. 1(A), (C), and (B), respectively. Other BN peaks were too weak to give useful information. The integrated intensity ratios indicate that $\mathrm{BN}$ platelets were mostly aligned with their $c$-axes in the hot-pressing direction. The preferred orientation of the lubricious BN platelets due to hot-pressing should result in low shear strength on planes normal to the pressing direction. From the moderate intensity of the $(002)_{\mathrm{BN}}$ from the side of the specimen (cross section in Fig. 1(C)), there also appears to be some alignment of the $\mathrm{BN}$ platelets with their $c$-axes normal to the pressing direction and the cell axes. This alignment must result from slurry application on the green fibers.

Surface damage from a Vickers indentation is shown in Fig. 4. The section of a chopped fiber pellet parallel to the pressing direction was indented. Indentation causes cells to spall or crack, with the soft $\mathrm{BN}$ being extruded out from the cell boundaries. Unlike classically brittle materials, long radial cracks do not form upon indentation. So, just as in $\mathrm{SiC} /$ graphite, ${ }^{6}$ strength would be unaffected by point contact damage. 


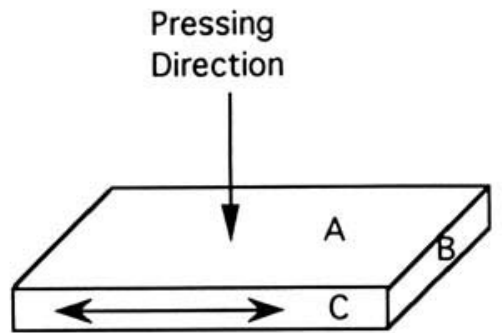

Fiber Alignment

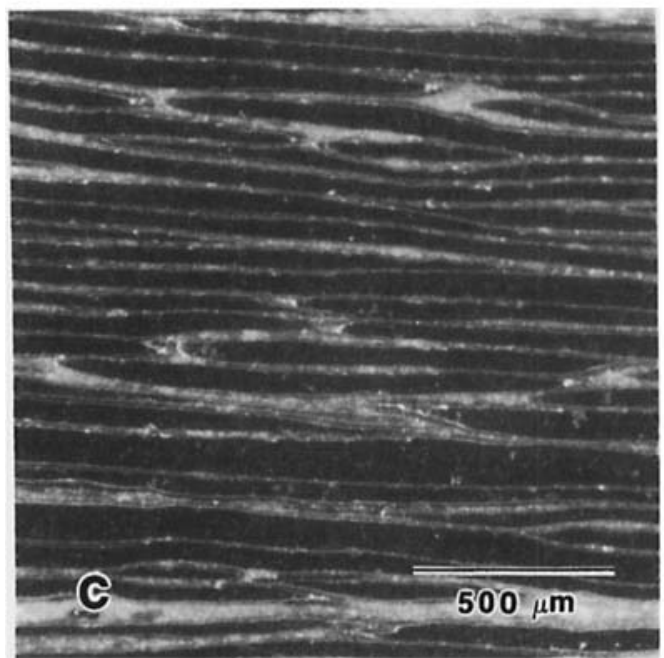

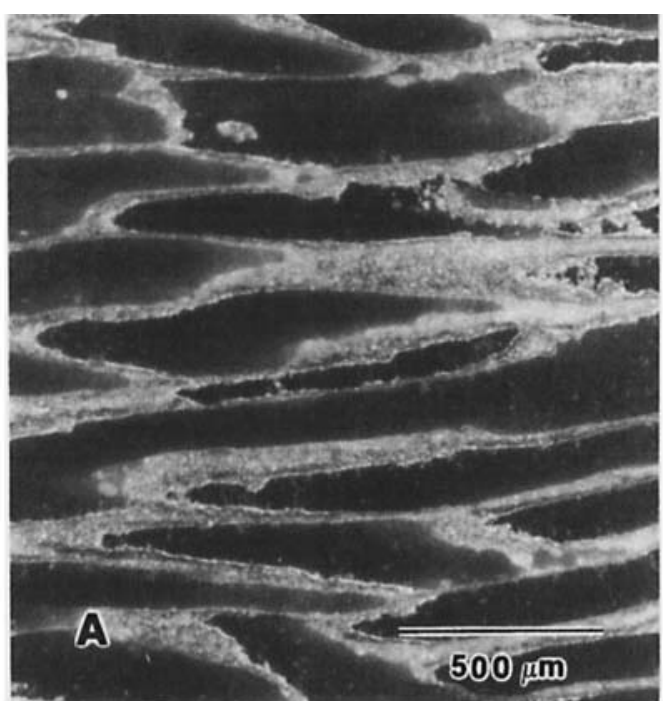

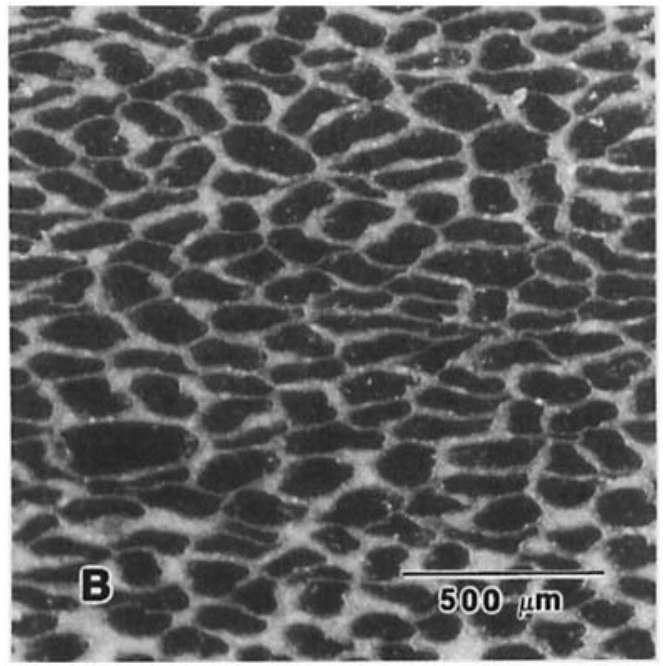

Fig. 1. Optical micrographs of a $\mathrm{SiC} / \mathrm{BN}$ fibrous monolith prepared with aligned green fibers showing polycrystalline $\mathrm{SiC}$ cells (dark) and $\mathrm{BN}$ cell boundaries (light).
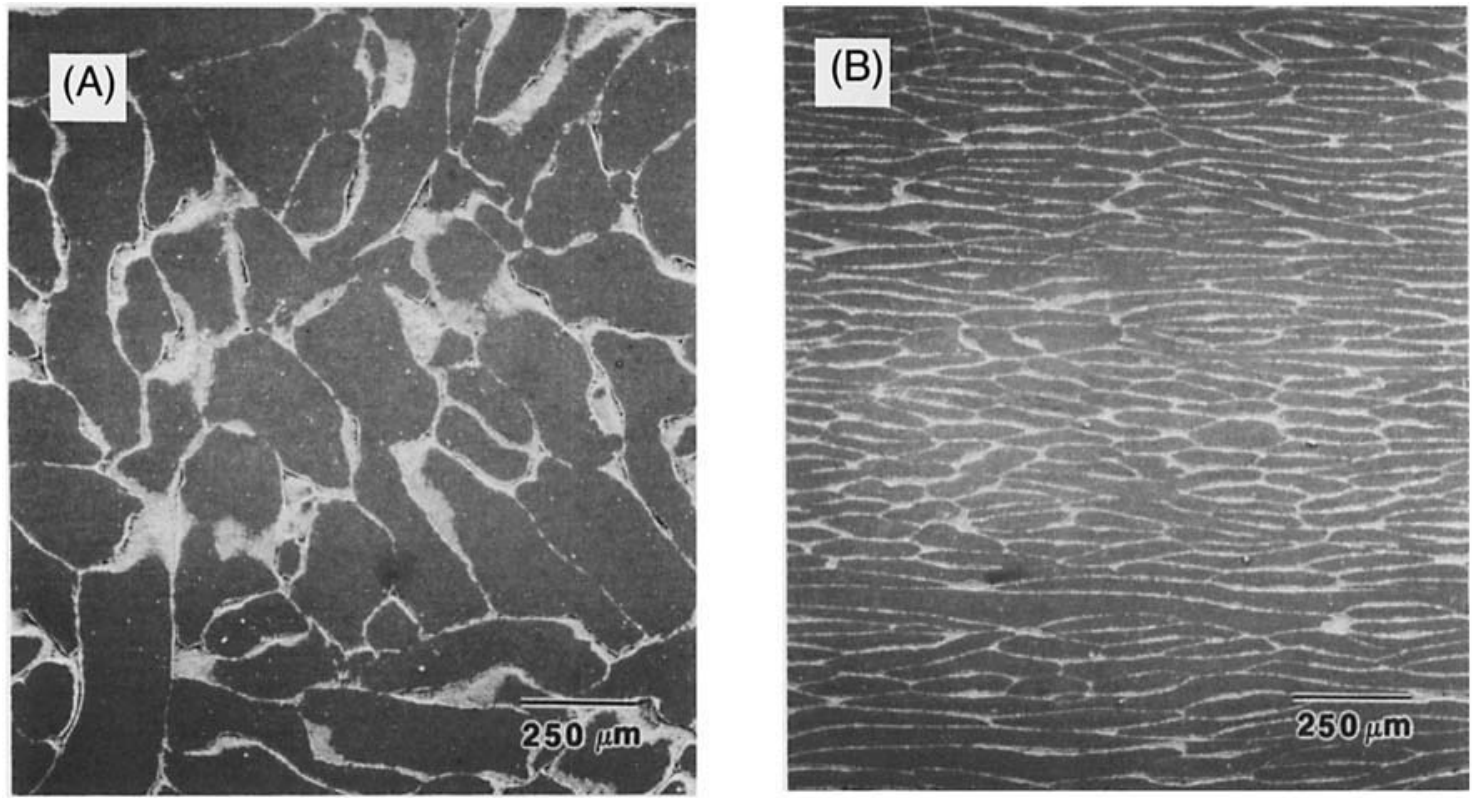

Fig. 2. SEM micrographs of polished surfaces of a SiC/BN fibrous monolith prepared with finely chopped, randomly oriented fibers (A) viewed in the hot-pressing direction and $(\mathrm{B})$ viewed normal to the hot-pressing direction. 


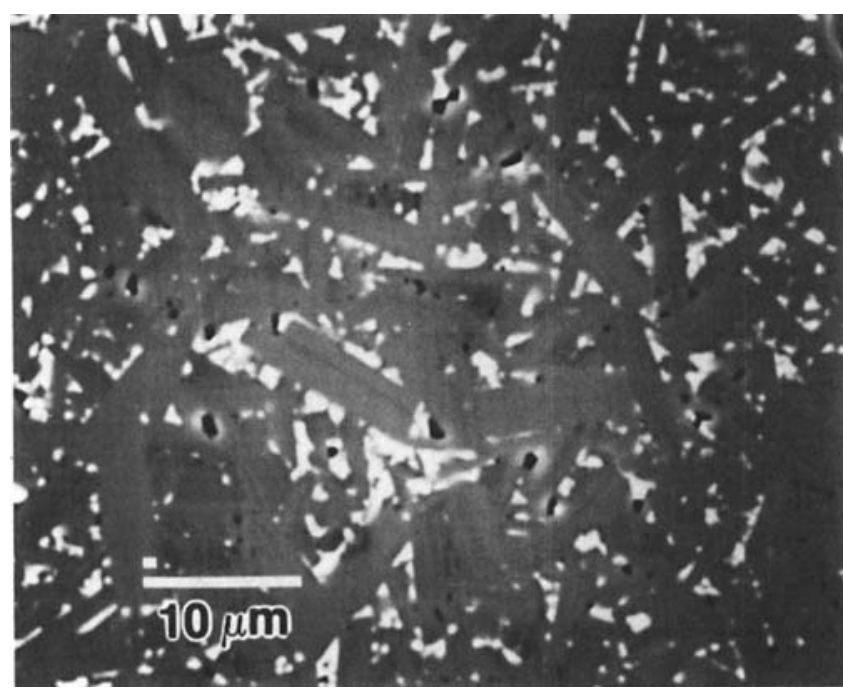

Fig. 3. Backscattered electron image of a $\mathrm{SiC}$ cell showing elongated grains of $\mathrm{SiC}$ (gray), and the yttria-alumina intergranular phase (white).

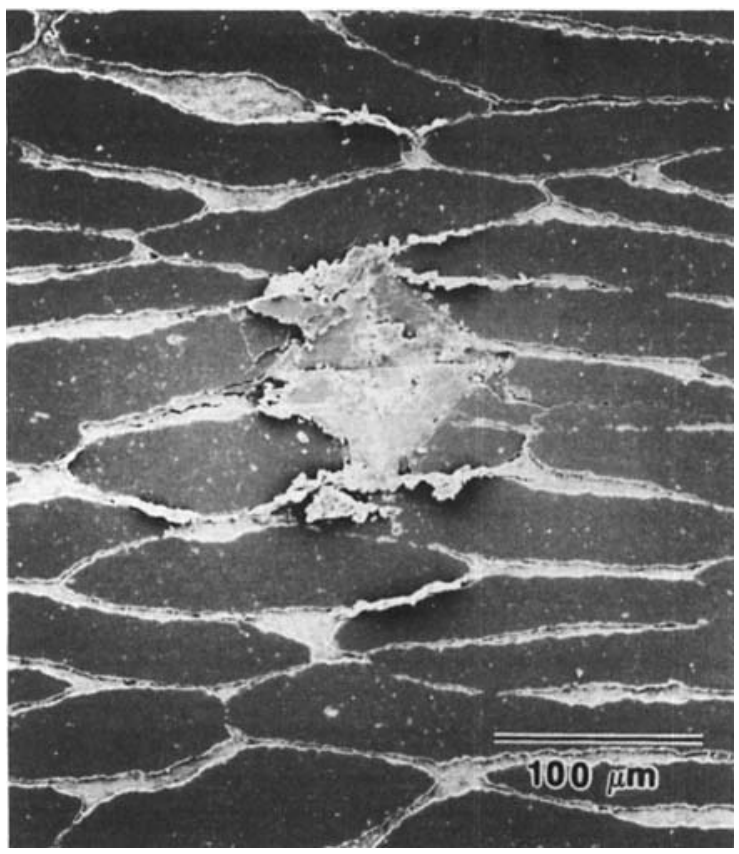

Fig. 4. SEM micrograph showing indentation fracture in a $\mathrm{SiC} / \mathrm{BN}$ fibrous monolith (load $=50 \mathrm{~N}$ ). Indented surface was parallel to the hot-pressing direction. Note extrusion of cell boundary material and absence of long radial cracks.

\section{(2) Flexural Strength and Fracture Behavior}

Load-deflection curves for two sample geometries of aligned-fiber $\mathrm{SiC} / \mathrm{BN}$ are compared with data for a SiC monolith ${ }^{11}$ in Fig. 5. The applied stress value is meaningful until the first load drop in each of the samples. The SiC monolith shows high strength but brittle fracture behavior. The fibrous monoliths for both span-to-depth ratios display noncatastrophic fracture behavior, with significant load-retaining capability after fracture commences. The lower modulus of the fibrous monolith is apparent from the lower slope of the 3-mm-thick SiC/BN specimen compared to $\mathrm{SiC}$.

The strength values and modes of fracture were very similar to the $\mathrm{SiC} / g r a p h i t e .{ }^{6}$ For thin specimens, fracture initiated from the tension side, and the sample then proceeded to delaminate like wood. The flexural strength values measured at this high

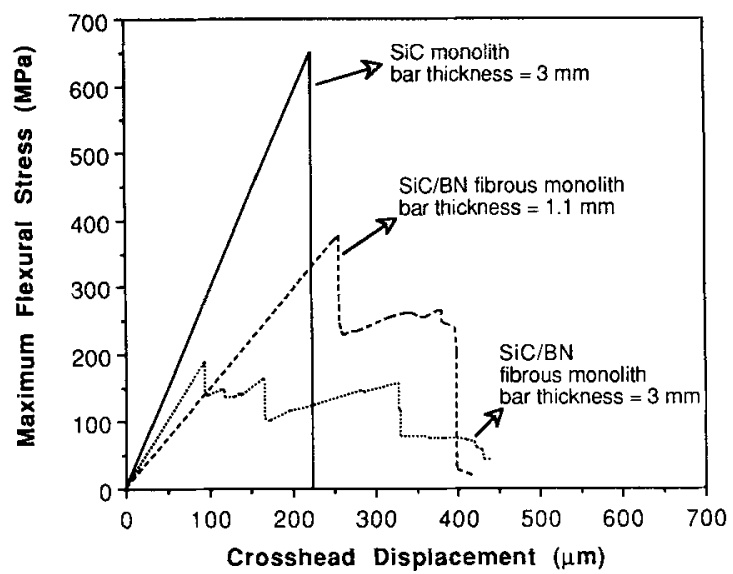

Fig. 5. Flexural strength behavior of aligned-fiber $\mathrm{SiC} / \mathrm{BN}$ compared to monolithic $\mathrm{SiC}$. Load-deflection traces for the fibrous monolith at two different span-to-depth ratios are shown.

span-to-depth ratio were in the range $300-375 \mathrm{MPa}$. For thick specimens, the samples shear-cracked starting at the midplane of the bar specimens between an inner and an outer loading point, where applied shear stresses are highest. The apparent strength of $186 \mathrm{MPa}$ is not meaningful, since failure begins when the applied $\tau_{\text {midplane }}$ reaches the shear strength of the material. The interlaminar shear strength estimated from the thick specimens using elastic beam equations $s^{6,12}$ was $14.1 \mathrm{MPa}$. The side surface after the test for a 3 -mm-thick specimen is shown in Fig. 6. Extensive delamination cracking occurs along the length of the bar specimen. An apparent work-of-fracture measured from the area under the load-displacement curve and the specimen cross-sectional area was $2430 \mathrm{~J} / \mathrm{m}^{2}$.

The load-deflection behavior for a chopped-fiber bar specimen in flexure is presented in Fig. 7(A). The strength is 128 $\mathrm{MPa}$, almost identical to the strength of $\mathrm{SiC} /$ graphite with similar cell architecture. ${ }^{6}$ The side surface of the specimen after testing is shown in Fig. 7(B). Fracture initiates at the weak cell boundaries normal to the applied stress on the tension side. The shear characteristics of the material cause the crack to deflect towards the bar axis and propagate along the weak cell boundaries. The specimen does not fall apart after the test, but has almost no load-bearing capability.

From the cell architectures studied, it appears that, with suitable fiber lay-up methods, $\mathrm{SiC} / \mathrm{BN}$ fibrous monoliths can be fabricated with sufficient strength and tough fracture behavior. Earlier work with $\mathrm{SiC} /$ graphite $^{11}$ has shown that the off-axis strength in aligned fibrous monoliths is low $(\approx 70 \mathrm{MPa})$, but

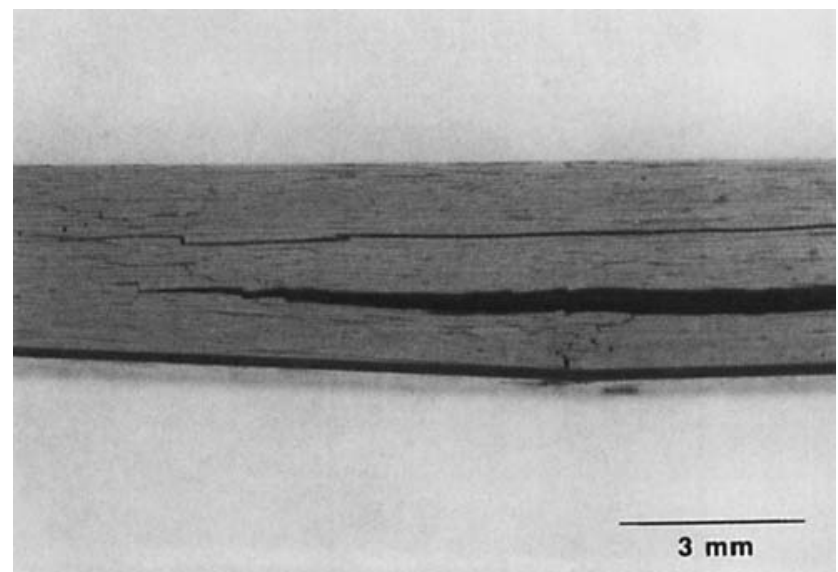

Fig. 6. Side surface of $\mathrm{SiC} / \mathrm{BN}$ bend specimen after test showing delamination cracking (optical micrograph). 

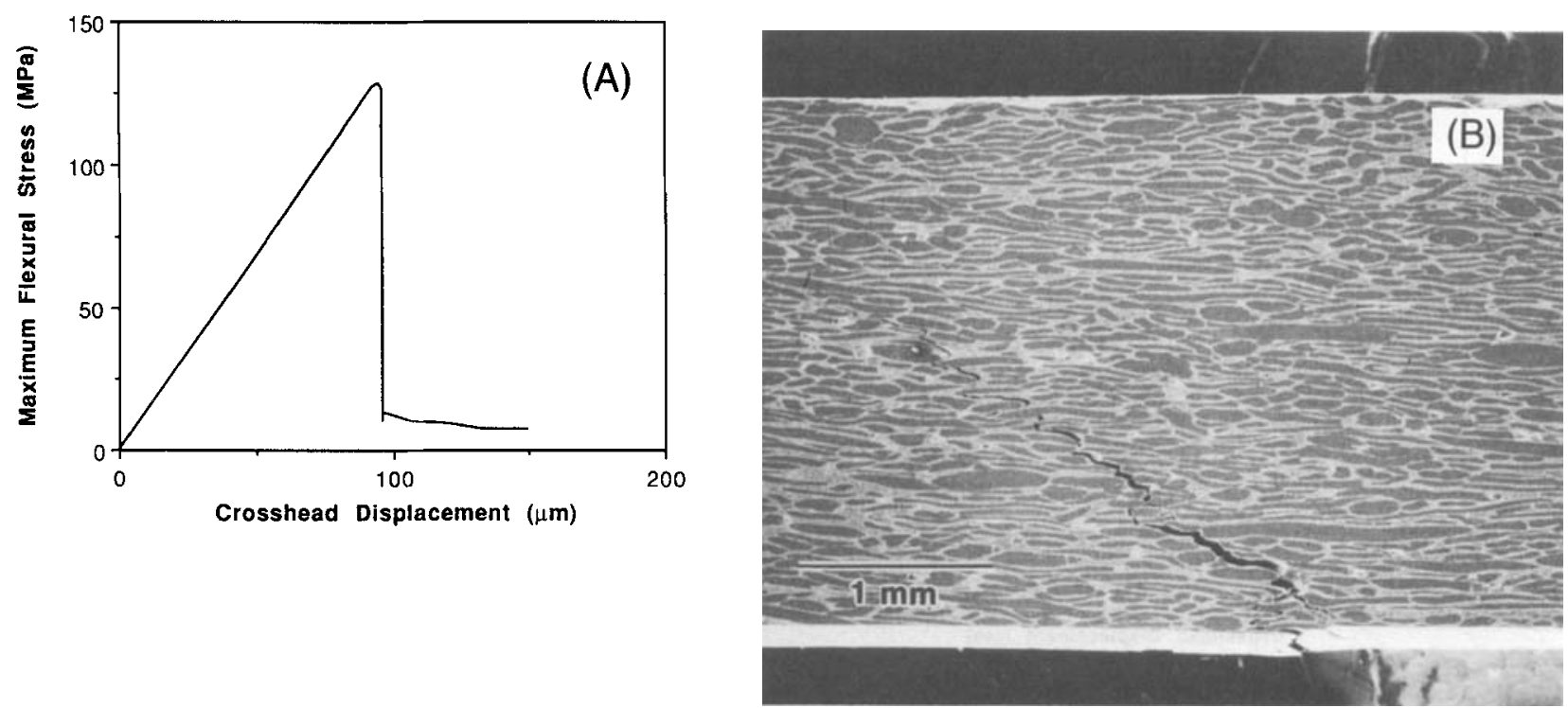

Fig. 7. (A) Flexural strength behavior of chopped-fiber SiC/BN. (B) SEM micrograph of the side surface of the specimen after test.

a $0^{\circ} / 90^{\circ}$ cross-ply structure has strength $\approx 150 \mathrm{MPa}$. Other microstructural arrangements such as woven fabrics of $\mathrm{SiC} / \mathrm{BN}$ may have a combination of tensile and shear strengths that meets design requirements of some structural components.

\section{(3) Effect of Oxidation}

The room-temperature strength behavior of oxidized bars after 10 -h heat treatments at $1200^{\circ}$ to $1500^{\circ} \mathrm{C}$ in air is shown in Fig. 8. Noncatastrophic fracture behavior is observed even in samples heat-treated to $1500^{\circ} \mathrm{C}$. All samples were glazed after heat treatment. The bar specimens' thickness and width had increased about $3 \%-4 \%$. The high temperature $\left(1400^{\circ}\right.$ and $1500^{\circ} \mathrm{C}$ ) heat treatments resulted in substantial bubble formation, with gas entrapment and foaminess in the scale. In the sample held at $1500^{\circ} \mathrm{C}$, the scale had foamed up a few millimeters, presumably because of lower viscosity of the scale at the high temperature. For this specimen, the foam was scraped off before testing. In Fig. 8, the apparent strengths are again not meaningful and do not reflect the true flexural strength of the materials. For all samples, failure initiated by midplane shear cracking, followed by extensive damage primarily below the inner loading point. The oxidation treatment had apparently not affected the shear properties (i.e., not affected the bulk of the BN cell boundaries) significantly. Then the bar specimen shear cracked between an inner and outer loading point, which chipped off part of the scale, as shown in Fig. 9.

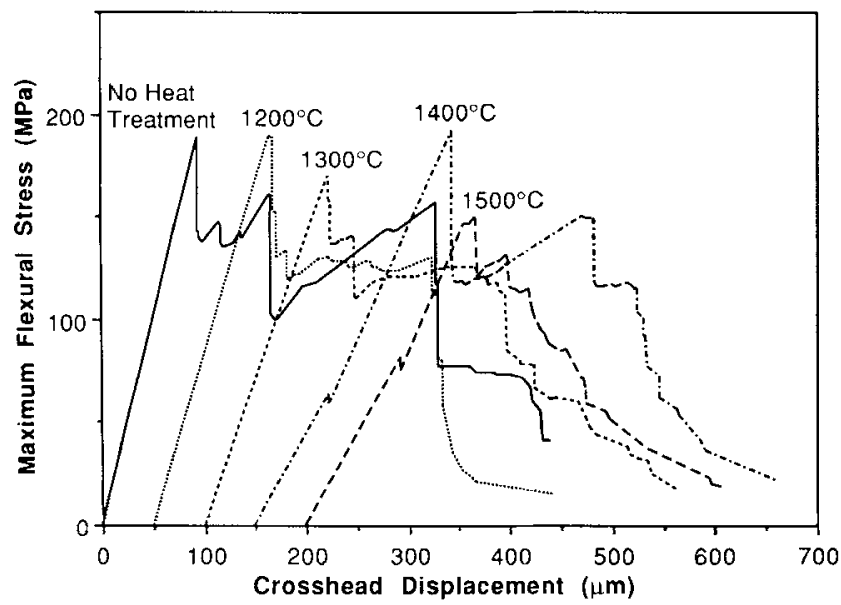

Fig. 8. Room-temperature strength behavior of aligned-fiber $\mathrm{SiC} / \mathrm{BN}$ after 10 -h heat treatments in air at high temperatures.
The room-temperature load deflection behavior of bar specimens heat-treated at $1400^{\circ}$ for 10,50 , and $250 \mathrm{~h}$ is shown in Fig. 10. Here again, all samples failed by shear delamination along the cell boundaries. Noncatastrophic fracture behavior was recorded even after $250 \mathrm{~h}\left(>10\right.$ days) at $1400^{\circ} \mathrm{C}$. The bar that had undergone the long 250 -h heat treatment was covered with a foamy, translucent scale. The side surface of this bar in Fig. 11 shows delamination cracking and damage in the section below the inner loading point. The fibrous structure is visible in regions where the scale has come off.

Table I lists the room-temperature flexure properties for all the $\mathrm{SiC} / \mathrm{BN}$ samples after heat treatment. Interlaminar shear strengths calculated from the maximum flexural stress are generally low after all the heat treatments. The long $1400^{\circ} \mathrm{C}$ hold results in some increase in the shear strength to $18 \mathrm{MPa}$. Apparent work-of-fracture values are also high for all the specimens.

The polished section of a bar specimen after $1400^{\circ} \mathrm{C} / 250 \mathrm{~h}$ is compared with an untreated sample in Fig. 12. The optical micrographs show the chamfered corners of the bar section. The scale on the heat-treated sample is $25-50 \mu \mathrm{m}$ thick on average, and $>100 \mu \mathrm{m}$ thick in some areas. There was no measurable

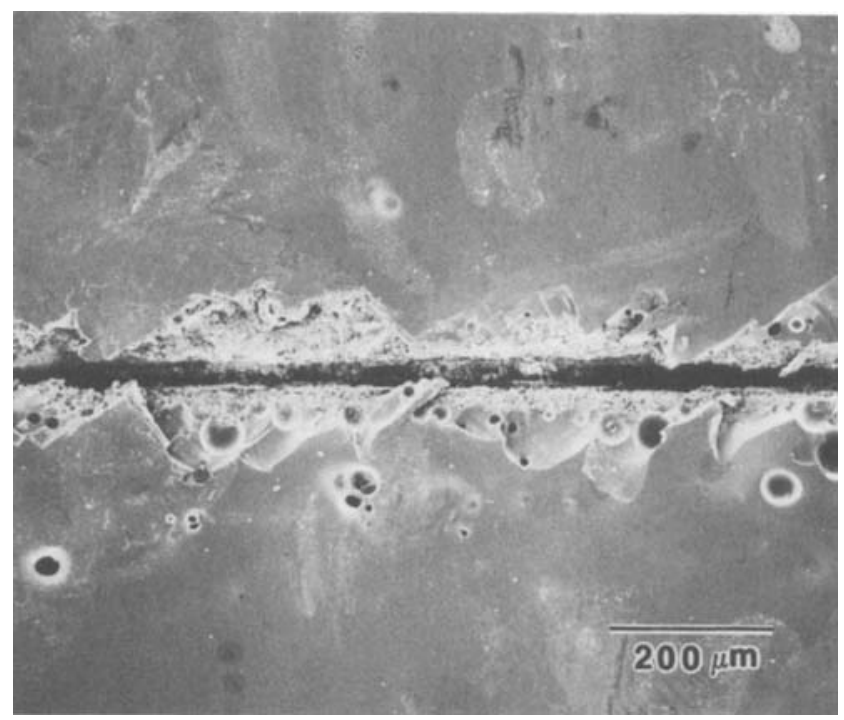

Fig. 9. SEM micrograph showing side surface of heat-treated $\left(1400^{\circ} \mathrm{C} / 10 \mathrm{~h}\right) \mathrm{SiC} / \mathrm{BN}$ specimen after bend test. 


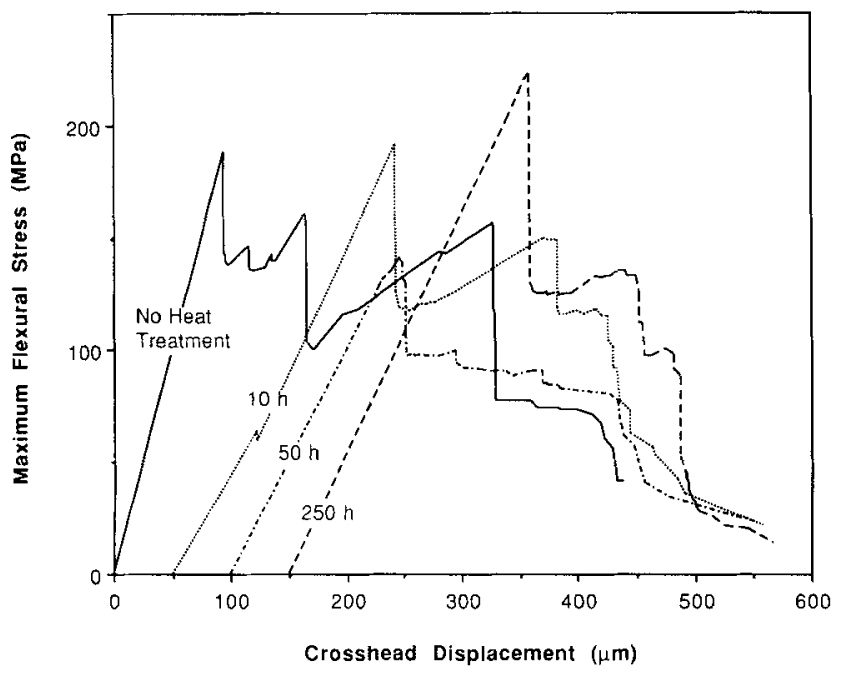

Fig. 10. Room-temperature strength behavior of aligned-fiber $\mathrm{SiC} /$ BN heat-treated at $1400^{\circ} \mathrm{C}$ in air for various times.

Table I. Room-Temperature Properties of Aligned-Fiber SiC/BN from Flexure Tests

\begin{tabular}{lccc}
\hline \multicolumn{1}{c}{ Heat treatment } & $\sigma_{\text {nax }}(\mathrm{MPa})$ & $\tau_{\text {fillari }}(\mathrm{MPa})$ & $\begin{array}{c}\text { Apparent work- } \\
\text { of-fracture }\left(\mathrm{J} / \mathrm{m}^{3}\right)\end{array}$ \\
\hline None & 186 & 14.1 & 2430 \\
$1200^{\circ} \mathrm{C}(10 \mathrm{~h})$ & 189 & 14.7 & 1770 \\
$1300^{\circ} \mathrm{C}(10 \mathrm{~h})$ & 171 & 13.5 & 2130 \\
$1400^{\circ} \mathrm{C}(10 \mathrm{~h})$ & 192 & 15.6 & 2210 \\
$1500^{\circ} \mathrm{C}(10 \mathrm{~h})$ & 146 & 11.6 & 1480 \\
$1400^{\circ} \mathrm{C}(50 \mathrm{~h})$ & 141 & 11.3 & 1800 \\
$1400^{\circ} \mathrm{C}(250 \mathrm{~h})$ & 223 & 18.0 & 2230 \\
\hline
\end{tabular}

change in the cell and cell boundary dimensions. There was also no evidence of degradation or reactions in the cell boundaries or cells in the interior of the sample. This is consistent with retention of low-shear-strength $\mathrm{BN}$ cell boundaries and noncatastrophic fracture behavior even after $10 \mathrm{~d}$ at $1400^{\circ} \mathrm{C}$.

A backscattered electron image of a polished section of heattreated $\mathrm{SiC} / \mathrm{BN}$ is shown in Fig. 13. The micrograph shows the

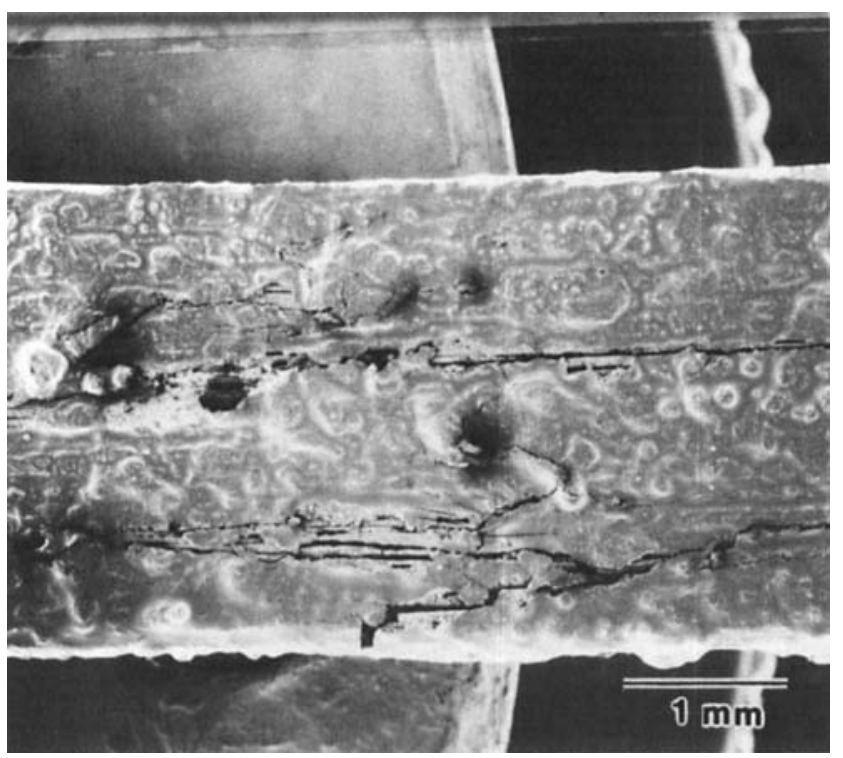

Fig. 11. SEM micrograph showing side surface of heat-treated $\left(1400^{\circ} \mathrm{C} / 250 \mathrm{~h}\right) \mathrm{SiC} / \mathrm{BN}$ specimen after bend test. scale appearing in bright contrast. The scale contains faceted inclusions. The SiC cell in the interior, as in Fig. 3, shows bright $\mathrm{Y}$ - and Al-containing intergranular phases. Elemental microanalysis was done on the different phases in many areas of this sample, as well as on unoxidized samples. The bright scale contained yttrium, aluminum, silicon, and oxygen. The inclusion was a crystalline form of silica, most likely cristobalite. ${ }^{18}$ There was no evidence of an oxidation product of $\mathrm{BN}$ extending into the $\mathrm{BN}$-rich cell boundary. It was not possible to determine whether boron was present in the scale, since our spectrometer could not detect boron in this sample. A wavelength spectrometer scan of the emissions from the scale did not show the characteristic peak for nitrogen, which indicated that there was no dissolved $\mathrm{N}$ in the glass. The compositions of the cell phase were the same in the unoxidized and heat-treated samples. Some pieces of monolithic $\mathrm{SiC}$ (with the same yttria-alumina additions) were also heat-treated for comparison. Similar oxide scale formation was observed in these samples, with identical elemental compositions.

From the microstructural observations and elemental analysis, it is evident that the SiC cells on the surface are oxidized to form a protective layer of $\mathrm{Y}-\mathrm{Al}$-containing silicate scale with $\mathrm{SiO}_{2}$ inclusions. $\mathrm{BN}$ appears to be unoxidized beneath this scale even after long-term exposure at $1400^{\circ} \mathrm{C}$. The stability of $\mathrm{BN}$ in this environment can be explained in terms of the equilibrium partial pressures of oxygen expected at $\mathrm{SiC} / \mathrm{SiO}_{2}$ and $\mathrm{BN} / \mathrm{B}_{2} \mathrm{O}_{3}$ interfaces at $1400^{\circ} \mathrm{C}$. The oxidation of $\mathrm{SiC}$ is assumed to be controlled both by diffusion and interface reaction, as suggested by Luthra. ${ }^{18}$ The most probable reaction for the oxidation of $\mathrm{SiC}$ cells is

$$
\mathrm{SiC}+\frac{3}{2} \mathrm{O}_{2} \rightarrow \mathrm{SiO}_{2}+\mathrm{CO}
$$

From free energies of formation, ${ }^{19} \Delta G$ for the above reaction can be calculated. With this information, and assuming 1 bar $(\approx 1 \mathrm{~atm})$ pressure of $\mathrm{CO}$ at the interface, the equilibrium $P_{\mathrm{O}}$, at the $\mathrm{SiC} / \mathrm{SiO}_{2}$ interface has been estimated to be $\approx 7 \times$ $10^{-17}$ atm.

The oxygen partial pressure required for $\mathrm{BN}$ oxidation can also be calculated from the free-energy change of the reaction

$$
2 \mathrm{BN}+\frac{3}{2} \mathrm{O}_{2} \rightarrow \mathrm{B}_{2} \mathrm{O}_{3}+\mathrm{N}_{2}
$$

The nitrogen partial pressure beneath the scale can be assumed to be 1 bar. The equilibrium $P_{\mathrm{O}_{2}}$ at a hypothetical $\mathrm{BN} / \mathrm{B}_{2} \mathrm{O}_{3}$ interface is then calculated to be $1.5 \times 10^{-14}$. This value of oxygen partial pressure is $\approx 150$ times the equilibrium $P_{\mathrm{O}_{2}}$ at $\mathrm{SiC} / \mathrm{SiO}_{2}$ interfaces. The calculated value for the $P_{\mathrm{O}_{2}}$ at the $\mathrm{SiC} / \mathrm{SiO}_{2}$ interface is not expected to be significantly different when the oxidation product is a $\mathrm{Y}-\mathrm{Al}-\mathrm{Si}-\mathrm{O}$ scale containing $\mathrm{SiO}_{2}$ inclusions. The low equilibrium $P_{\mathrm{O}}$, associated with $\mathrm{SiC}$ oxidation establishes the oxygen partial pressure beneath the scale; this pressure is then too low for BN oxidation at $1200^{\circ}-1500^{\circ} \mathrm{C}$. The material retains low interlaminar shear strength BN cell boundaries after heat treatment, resulting in graceful failure behavior at room temperature. Further work on oxidation and high-temperature flexure properties is under way and will be reported in subsequent papers.

\section{Conclusion}

SiC-based fibrous monoliths with weak cell boundaries of $\mathrm{BN}$ show potentially useful mechanical properties at room temperature. Noncatastrophic fracture behavior with significant load-bearing capability is observed in $\mathrm{SiC} / \mathrm{BN}$ with aligned green fibers. As in SiC/graphite, delamination cracking of the $\mathrm{BN}$ cell boundaries occurs during failure. Young's modulus of $\mathrm{SiC} / \mathrm{BN}$ with aligned fibers is $\approx 340 \mathrm{GPa}$. Flexural strength is in the range $300-375 \mathrm{MPa}$, and interlaminar shear strength on planes normal to the pressing direction is $\approx 14 \mathrm{MPa}$. The low shear strength should render the material notch-insensitive under flexural loading conditions. Delamination cracks initiated 

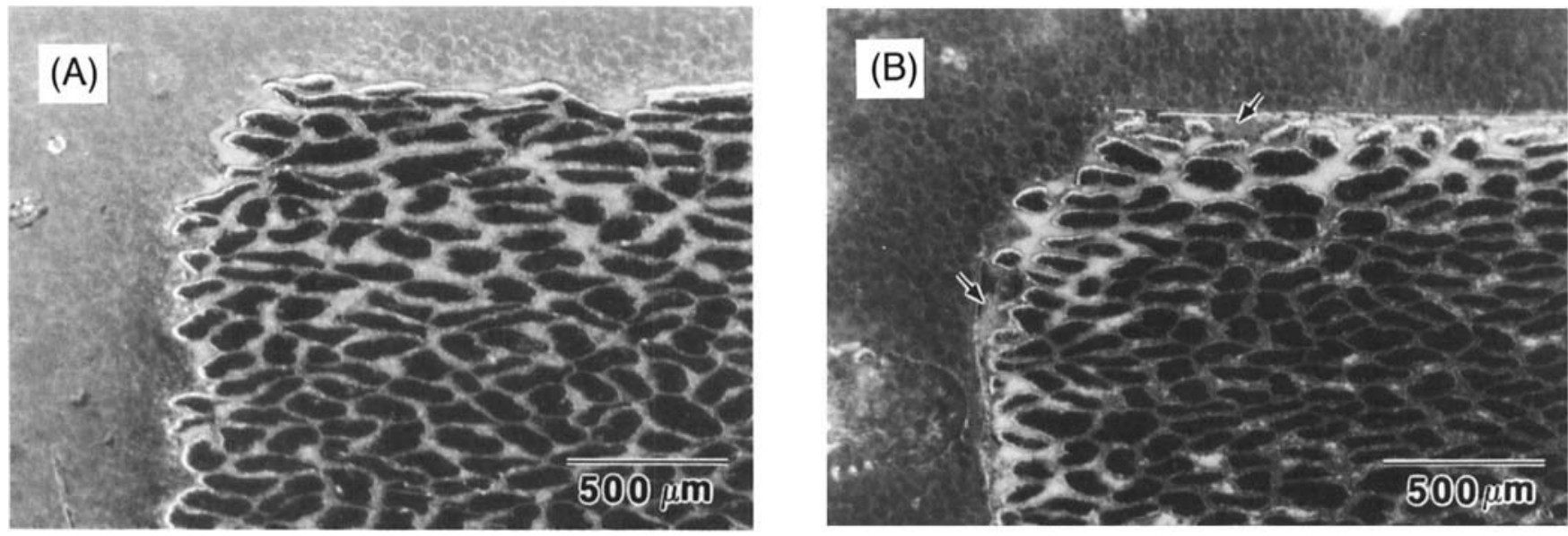

Fig. 12. Optical micrographs comparing polished cross sections of (A) unoxidized $\mathrm{SiC} / \mathrm{BN}$ and (B) SiC/BN after $1400^{\circ} \mathrm{C} / 250 \mathrm{~h}$. Scale is indicated by arrows.

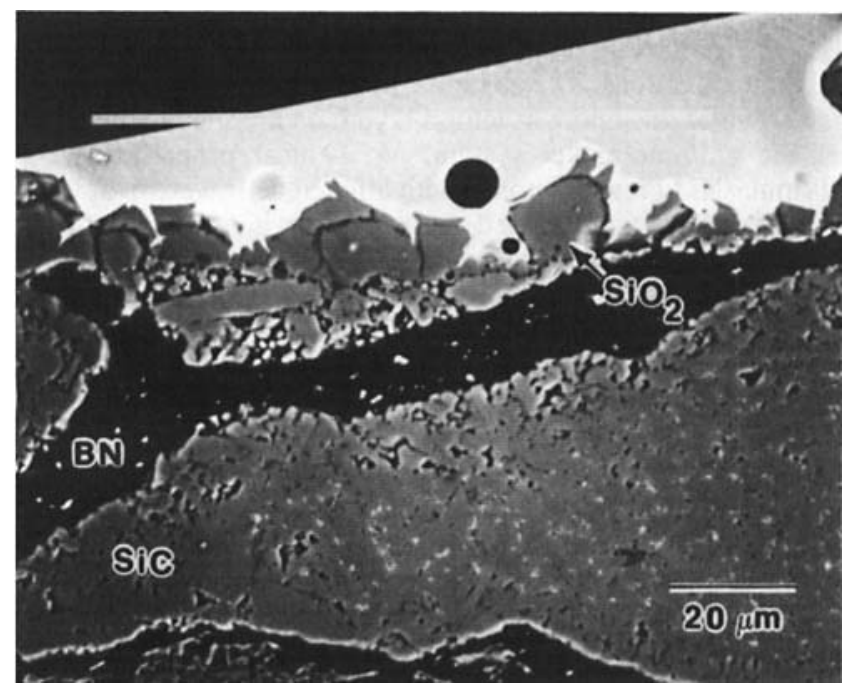

Fig. 13. Backscattered electron image of a polished section of $\mathrm{SiC} /$ BN heat-treated to $1400^{\circ} \mathrm{C} / 250 \mathrm{~h}$. The edge of the sample is shown with the various phases labeled.

from notch tips will cause the load to rise even after cracking has begun. ${ }^{6}$

The $\mathrm{SiC} / \mathrm{BN}$ system also shows potential for use in oxidizing environments at high temperatures. The low-shear-strength BN cell boundaries are retained even after heat treatment at $1400^{\circ} \mathrm{C}$ for 10 days in air. The oxidation of $\mathrm{SiC}$ cells on the surface forms a protective silicate layer preventing the oxidation of subsurface BN cell boundaries. Shear cracking and noncatastrophic failure is observed in room-temperature flexure tests after heat treatments in air between $1200^{\circ}$ and $1500^{\circ} \mathrm{C}$. Further studies on these materials will include evaluation of high-temperature mechanical properties, and microstructural refinement of the cell and cell boundary phases to optimize properties.
Acknowledgments: Lynne Svedberg and Tim Fretter provided assistance in fiber spinning. Carl Henderson performed the microprobe analysis. The authors also acknowledge useful discussions with Cynthia Arens.

\section{References}

K. M. Prewo and J. J. Brennan, "High Strength Silicon Carbide Fiber-Reinforced Glass-Matrix Composites," J. Mater. Sci., 15, 463-68 (1980).

${ }^{2}$ K. M. Prewo, "Fiber-Reinforced Ceramics: New Opportunities for Composite Applications," Am. Ceram. Soc. Bull., 68 [2] 395-400 (1989).

W. J. Clegg, K. Kendall, N. McN. Alford, T. W. Button, and J. D. Birchall, "A Simple Way to Make Tough Ceramics," Nature, 347, 455-57 (1990).

${ }^{4}$ W. S. Coblenz, "Fibrous Monolithic Ceramic and Method for Production,"

U.S. Pat. No. 4772524, September 20, 1988.

'S. Raskaran, S. D. Nunn, D. Popovic, and J. W. Halloran, "Fibrous Monolithic Ceramics: I, Fabrication, Microstructure, and Indentation Behavior," J. Am. Ceram Soc 76 [9] 2209-16 (1993).

"S. Baskaran and J. W. Halloran, "Fibrous Monolithic Ceramics: II, Flexural Strength and Fracture Behavior of the Silicon Carbide/Graphite System," J. Am. Ceram. Soc., 76 [9] 2217-24 (1993).

${ }^{7} \mathrm{C}$. Arens, "Oxidation of Fibrous Monolithic Ceramics"; M.S. thesis in progress, University of Michigan, Ann Arbor, MI, unpublished work.

${ }^{8}$ R. N. Singh and M. K. Brun, "Effect of Boron Nitride Coating on FiberMatrix Interactions," Ceram. Eng. Sci. Proc., 8 [7-8] 636-43 (1987).

${ }^{9}$ R. N. Singh and A. R. Gaddipati, "Mechanical Properties of a Uniaxially Reinforced Mullite-Silicon Carbide Composite," J. Am. Ceram. Sor., 71 [2] C-100-C-103 (1988)

'J. J. Brennan, "Glass and Glass-Ceramic Matrix Composites"; presented at the 95th Annual Meeting of the American Ceramic Society, Cincinnati, OH, April 1993 (Paper No. SII-81-93).

${ }^{1}$ S. Baskaran and J. W. Halloran, "SiC-based Fibrous Monolithic Ceramics," Ceram. Eng. Sci. Proc., in press.

${ }^{12}$ D. B. Marshall and A. G. Evans, "Failure Mechanisms in Ceramic-Fiber/ Ceramic-Matrix Composites,"J. Am. Ceram. Soc., 68 [5] 225-31 (1985).

${ }^{13}$ E. Schreiber, O. L. Anderson, and N. Soga, Elastic Constants and Their Measurement; Ch. 4. McGraw-Hill, New York, 1973.

${ }^{14}$ S. Spinner and W. E. Tefft, "A Method for Determining Mechanical Resonance Frequencies and for Calculating Elastic Moduli from these Frequencies," Proc. Am. Soc. Test. Mater, 61, 1229 (1961).

${ }^{15}$ S. J. Schneider (Ed.), Engineering Materials Handbook, Vol. 4, Ceramics and Glass, Sect. II, Properties of Carbides. ASM International, Metals Park, $\mathrm{OH}, 1991$.

${ }^{16}$ A. Lipp, K. A. Schwetz, and K. Harold, "Hexagonal Boron Nitride: Fabrication, Properties and Applications," J. Eur. Ceram. Soc., 5, 3-9 (1989).

${ }^{17}$ R. Ruh. A. Zangvil, and R. R. Wills, "Phase and Property Studies of SiC/BN Composites," Adv. Ceram. Mater., 3 [4] 41 1-15 (1988).

${ }^{18}$ K. L. Luthra, "Some New Perspectives on Oxidation of Silicon Carbide and Silicon Nitride," J. Am. Ceram. Soc., 74 [5] 1095-103 (1991).

${ }^{19}$ D. R. Stull and H. Prophet (Eds.), JANAF Thermochemical Tables, 2 nd ed. National Bureau of Standards, Washington, DC, 1971. 